\title{
Pengaruh Pemberian Ekstrak Alga Merah (Gracilaria verrucosa) terhadap Aktivitas SGPT pada Tikus Putih (rattus norvegicus) Jantan Galur Wistar yang Diinduksi Parasetamol Dosis Tinggi
}

\author{
Akbar Maharudin Fikri ${ }^{1 *}$, Sihning EJ Tehupuring ${ }^{2}$ \\ Fakultas Kedokteran Universitas Hang Tuah Surabaya ${ }^{1,2}$ \\ *e-mail: bigbus98@gmail.com
}

\begin{abstract}
Abstrak
Pemberian parasetamol dosis tinggi dapat meningkatkan jalur metabolisme yang menghasilkan $N$-asetil-p-benzoquinonimin (NAPQI). NAPQI bersifat reaktif sehingga mengakibatkan kerusakan jaringan hepar dan meningkatkan aktivitas SGPT. Ekstrak alga merah mengandung flavonoid yang berfungsi sebagai antioksidan. Penelitian ini bertujuan untuk mengetahui pengaruh pemberian ekstrak alga merah (Gracilaria verrucosa) terhadap aktivitas Serum Glutamic Pyruvic Transaminase (SGPT) tikus putih (Rattus norvegicus) jantan galur Wistar yang diinduksi parasetamol dosis tinggi. Penelitian ini menggunakan sampel 24 ekor tikus putih jantan galur Wistar yang dibagi menjadi 3 kelompok, yaitu kelompok hewan coba yang diberi pakan standar, kelompok hewan coba yang diberi parasetamol $1750 \mathrm{mg} / \mathrm{kgBB}$ pada hari ke 10 dan kelompok hewan coba yang diberi ekstrak alga merah $200 \mathrm{mg} / \mathrm{kgBB} /$ hari pada hari ke 1-11 dan parasetamol $1750 \mathrm{mg} / \mathrm{kgBB}$ pada hari ke 10. Pada hari ke 11, hewan coba dikorbankan dan dilakukan pemeriksaan SGPT dengan metode spektrofotometri. Hasil uji Mann-Whitney menunjukkan perbedaan bermakna $(p=0,021)$ aktivitas SGPT antara kelompok hewan coba yang diberi pakan standar $(\bar{x}=81,95 \pm 10,103 \mathrm{U} / \mathrm{L})$ dan kelompok hewan coba yang diberi parasetamol dosis tinggi $(\bar{x}=97,06 \pm 11,19 \mathrm{U} / \mathrm{L})$. Selain itu, terdapat perbedaan bermakna $(p=0,016)$ aktivitas SGPT antara kelompok hewan coba yang diberi parasetamol dosis tinggi $(\bar{x}$ $=97,06 \pm 11,19 \mathrm{U} / \mathrm{L}$ ) dan kelompok hewan coba yang diberi parasetamol dosis tinggi dan ekstrak alga merah $(\bar{x}=82,73 \pm 11,233 \mathrm{U} / \mathrm{L})$. Kesimpulan hasil penelitian menunjukkan bahwa parasetamol dosis tinggi meningkatkan secara bermakna aktivitas SGPT dan ekstrak alga merah menurunkan secara bermakna aktivitas SGPT pada tikus yang diberi parasetamol dosis tinggi.
\end{abstract}

Kata Kunci: Parasetamol, SGPT, Gracilaria verrucosa

\section{Effect of Red Algae (Gracilaria verrunosa) Extract on SGPT Activity in White Male Rats (Rattus Norvegicus) Induced by High Dose Paracetamol}

\begin{abstract}
Administration of high dose paracetamol may increase the metabolic pathways that produce $N$-acetyl-p-benzoquinonimin (NAPQI). NAPQI is a reactive substance, resulting liver tissue damage and increase SGPT activity. Red algae extract contains flavonoids that act as antioxidants. This research aimed to determine the effect of red algae (Gracilaria verrucosa) extract to the activity of serum glutamic pyruvic transaminase (SGPT) in male Wistar rats (Rattus norvegicus) induced by high dose paracetamol. This research used 24 animal of Male Wistar rats. These rats were divided into 3 groups: group of rats fed with standard food; group of rats given paracetamol $1750 \mathrm{mg} / \mathrm{kg}$ on day 10; and group of rats given red algae extract 200
\end{abstract}


Pengaruh Pemberian Ekstrak Alga Merah (Gracilaria verrucosa) terhadap Aktivitas SGPT pada...

Akbar Maharudin Fikri, Sihning EJ Tehupuring

$\mathrm{mg} / \mathrm{kg} /$ day on day $1-11$ and paracetamol $1750 \mathrm{mg} / \mathrm{kg}$ on day 10 . On day 11 , all rats were sacrificed and SGPT activities were measured by spectrophotometry method. Mann-Whitney test results showed significant difference $(p=0.021)$ between SGPT activity of group of rats fed with standard food $(\bar{x}=81.95 \pm 10.103 \mathrm{U} / \mathrm{L})$ and group of rats induced by high dose paracetamol $(\bar{x}=97.06 \pm 11.19 \mathrm{U} / L)$. Furthermore, there was significant difference $(p=0.016)$ between SGPT activity of group of rats induced by high dose paracetamol $(\bar{x}=97.06 \pm 11.19 \mathrm{U} / \mathrm{L})$ and group of rats induced by high doses of paracetamol and fed with red algae extract $(\bar{x}=82.73 \pm 11.233$ $U / L)$. The conclusion of this research showed that high dose paracetamol significantly increased SGPT activity and red algae extract significantly decreased SGPT activity.

Keywords: Paracetamol, SGPT, Gracilaria verrucosa

\section{LATAR BELAKANG}

Hepar merupakan organ dalam terbesar pada tubuh manusia, menyumbang sekitar $2 \%$ berat tubuh total, atau sekitar 1,5 kg pada rata-rata manusia dewasa. Hepar berperan penting dalam proses metabolisme dan detoksifikasi obat dan senyawa beracun (Guyton dan Hall, 2008).

Penggunaan beberapa obat dalam dosis tinggi atau dalam jangka waktu yang lama seperti parasetamol dapat menyebabkan kerusakan pada hepar. Parasetamol (asetaminofen) merupakan obat analgetik non narkotik dengan cara kerja menghambat sistesis prostaglandin terutama di Siistem Saraf Pusat (SSP). Parasetamol digunakan secara luas di berbagai negara baik dalam bentuk sediaan tunggal sebagai analgesik-antipiretik maupun kombinasi dengan obat lain dalam sediaan obat flu, melalui resep dokter atau yang dijual bebas.
Di dalam hepar, sebagian besar parasetamol (>90\%) dimetabolisme menjadi asam glukuronat dan sulfat melalui glucuronyl transferase dan sulfonyl transferase dan kemudian diekskresi melalui urin. Sekitar 2\% tidak diubah dan diekskresi melalui urin, sekitar 5-10\% dimetabolisme oleh sitokrom P450 oleh enzim CYP2EI menjadi $N$-acetyl-pbenzoquinoneimine (NAPQI) yang merupakan molekul yang sangat reaktif dan bersifat elektrofilik yang dapat menyebabkan pembentukan ikatan kovalen antar protein intraseluler. Reaksi ini dapat dicegah melalui konjugasi dengan glutathione sehingga akan menghasilkan produk yang larut dalam air yaitu berupa asam merkapturat yang bersifat non toksik dan diekskresikan melalui urin (Chan et al., 2001).

Dalam kasus pembentukan NAPQI yang berlebihan atau kekurangan glutathione, maka NAPQI akan menyebabkan terjadinya stres oksidatif dan akan menyebabkan ikatan kovalen 
dengan makromolekul seluler seperti protein dan lipid membran. Sehingga hal tersebut akan menyebabkan kerusakan pada hepar (Farrel, 2014)

Adanya kerusakan pada hepar dapat dideteksi dengan melakukan pemeriksaan biokimia hati. Salah satunya adalah dengan menggunakan pemeriksaan enzim golongan transaminase, yaitu enzim aspartate aminotransferase (AST) atau sering disebut glutamate oksaloasetat transaminase (GOT) dan enzim alanine aminotransaminase (ALT) atau yang sering disebut glutamate piruvat transaminase (GPT). Kedua enzim ini akan keluar dari sel hati apabila sel hati mengalami kerusakan sehingga dengan sendirinya akan menyebabkan peningkatan aktivitasnya dalam serum darah (Gajawat, 2006). SGPT lebih sering digunakan sebagai indikator kerusakan atau nekrosis sel hati karena lebih sensitive daripada SGOT (Ghosh and Sil, 2007).

Untuk menetralkan stres oksidatif akibat dari NAPQI diperlukan antioksidan. Antioksidan adalah suatu bahan yang berfungsi mencegah sistem biologi tubuh dari efek yang merugikan yang timbul dari proses ataupun reaksi yang menyebabkan oksidasi berlebihan(Hariyatmi, 2004).

Alga merupakan salah satu sumber makanan yang mengandung senyawa antioksidan. Jenis alga di Indonesia yang mempunyai nilai ekonomis dan yang sering digunakan adalah alga merah (Gracilaria verrucosa) karena komposisinya sangat kompleks, yaitu agar-agar, karagenan, furcelaran, klorofil, karoten, fikobilin yang terdiri dari fikosianin dan fikoeritrin, protein, lemak, klor, kalium, natrium,magnesium, belerang, silicon, fosfor, kalsium,besi, iodium dan brom (Indriani dan Sumiarsih, 1991; Soegiarto et al., 1978)

Menurut penelitian Lestario dan kawan-kawan (2008) menyatakan bahwa alga merah (Gracilaria verrucosa) berpotensi sebagai antioksidan karena mengandung asam fenolik, flavonoid, klorofil a dan b serta karoten. Asam fenolik berperan sebagai antioksidan dengan menghambat beberapa enzim yang berperan pada pembentukan radikal bebas, seperti sitokrom P450, isoforms, lipoksigenase, siklooksigenase dan xanthin oksidase (Pereira et al, 2009). Flavonoid dapat menstabilkan radikal bebas dengan melengkapi kekurangan elektron dan menghambat terjadinya reaksi berantai dari pembentukan radikal bebas (Oktaviani et al, 2014). Struktur dari klorofil mengandung cincin porfirin. Senyawa dari klorofil dapat bertindak sebagai anti karsinogenik termasuk antioksidan. Mekanismenya adalah cincin porfirin akan bertindak sebagai molekul pemutus atau 
Pengaruh Pemberian Ekstrak Alga Merah (Gracilaria verrucosa) terhadap Aktivitas SGPT pada...

Akbar Maharudin Fikri, Sihning EJ Tehupuring

desmutagen. Selain itu, klorofil juga menstimulasi pertahanan seluler (Sato et al, 1980). Karotenoid dapat berfungsi sebagai peredam singlet oxygen dan pendeaktifasi radikal bebas (Panjaitan et al, 2005).

Antioksidan pada alga merah diduga dapat meredam NAPQI yang dihasilkan oleh parasetamol dosis tinggi pada hepar. Hal inilah yang mendasari dilakukannya penelitian yang berjudul pengaruh pemberian ekstrak alga merah (Gracilaria verrucosa) terhadap aktivitas SGPT pada tikus putih (Rattus novergicus) jantan galur Wistar yang diinduksi parasetamol dosis tinggi.

\section{METODE PENELITIAN}

Penelitian ini merupakan penelitian eksperimental yang dilakukan di dalam laboratorium. Populasi yang digunakan dalam penelitian ini adalah tikus putih (Rattus novergicus) jantan galur Wistar. Sampel yang dipakai adalah tikus Wistar jantan berumur 10-12 minggu dengan berat badan awal antara 150-200 gram sebanyak 24 ekor yang diperoleh dari Laboratorium Biokimia Fakultas Kedokteran Universitas Hang Tuah Surabaya.

Pemilihan sampel penelitian dilakukan dengan menggunakan metode simple random sampling. Metode penelitian ini merupakan post test only control group. Model rancangan ini baik kelompok ekspreimen maupun kelompok kontrol yang diperoleh dari kegiatan randomisasi, tidak dilakukan pretest. Kelompok eksperimen langsung dilakukan intervensi (perlakuan). Kemudian secara bersama-sama dengan kelompok kontrol dilakukan post test (Imron dan Munif, 2010).

Variabel bebas pada penelitian ini adalah ekstrak alga merah. Ekstrak alga merah diperoleh melalui proses ekstraksi dengan ethanol. Ekstrak alga merah diberikan pada tikus dengan dosis 200 $\mathrm{mg} / \mathrm{kgBB}$ per hari selama 11 hari. Variabel tergantung pada penelitian ini adalah aktivitas SGPT tikus putih (Rattus novergicus) jantan galur Wistar. Pemeriksaan aktivitas SGPT dalam darah ditentukan dengan metode Cobas Integra.

Dilakukan penghitungan rerata dan simpang baku aktivitas SGPT dari kelompok kontrol negatif, kelompok kontrol positif, dan kelompok perlakuan. Untuk mengetahui apakah terdapat perbedaan aktivitas SGPT yang bermakna antara kelompok tikus kontrol yang tidak mendapat parasetamol dan ekstrak alga merah (kelompok kontrol negatif), kelompok tikus yang mendapat parasetamol dosis tinggi tanpa ekstrak alga merah (kelompok kontrol positif), dan 
kelompok tikus yang mendapat parasetamol dosis tinggi dan ekstrak alga merah $200 \mathrm{mg} / \mathrm{kgBB} /$ hari (kelompok perlakuan), dilakukan uji statistika menggunakan One-Way Anova dengan tingkat kemaknaan $\alpha$ yang dipakai adalah $5 \%$.

\section{HASIL PENELITIAN}

Penelitian dilakukan di Laboratorium Biokimia Fakultas Kedokteran Umum Universitas Hang Tuah Surabaya selama 11 hari. Penelitian menggunakan 24 ekor tikus putih (Rattus norvegicus) jantan galur Wistar berumur 10-12 minggu yang dibagi dalam 3 kelompok yaitu:

1. Kelompok hewan coba yang diberi pakan standar

2. Kelompok hewan coba yang diberi parasetamol dosis tinggi

3. Kelompok hewan coba yang diberi parasetamol dan ekstrak alga merah (Gracilaria verrucosa)

Uji One-Way Annova merupakan uji parametrik yang digunakan untuk mengetahui apakah ada perbedaan bermakna pada semua kelompok hewan coba. Syarat uji One-Way Annova adalah distribusi data normal dan varian data homogen. Uji distribusi data menunjukkan bahwa distribusi data tidak normal, sehingga dilakukan uji Kruskal-Wallis.
Berdasarkan hasil analisa data, terdapat perbedaan bermakna $(p=0.021)$ antara rerata aktivitas SGPT pada kelompok hewan coba yang diberi pakan standar (81.95 U/L) dan aktivitas SGPT kelompok hewan coba yang diberi parasetamol dosis tinggi (97.06 U/L). Terdapat perbedaan bermakna $(p=0,016)$ antara rerata aktivitas SGPT pada kelompok hewan coba yang diberi parasetamol dosis tinggi (97.06 U/L) dan kelompok hewan coba yang diberi parasetamol dosis tinggi dan ekstrak alga merah $(82.73 \mathrm{U} / \mathrm{L})$.

\section{PEMBAHASAN}

Berdasarkan hasil analisis data, rerata aktivitas SGPT kelompok hewan coba yang hanya diberi parasetamol dosis tinggi $(97,06 \mathrm{U} / \mathrm{L})$ menunjukkan peningkatan yang bermakna $(p=0,021)$ bila dibandingkan dengan kelompok hewan coba yang hanya diberi pakan standar (81,95 U/L). Keadaan ini menunjukkan bahwa pemberian parasetamol dosis tinggi dapat meningkatkan secara bermakna aktivitas SGPT dibandingkan kelompok yang diberi pakan standar.

Parasetamol dimetabolisme terutama oleh enzim mikrosomal hati. Di hepar parasetamol dosis tinggi akan mengalami biotransformasi oleh sitokrom $\mathrm{P}_{450}$ menghasilkan metabolik toksik reaktif 
Pengaruh Pemberian Ekstrak Alga Merah (Gracilaria verrucosa) terhadap Aktivitas SGPT pada...

Akbar Maharudin Fikri, Sihning EJ Tehupuring

$\mathrm{N}$-asetil-p-benzoquinonimin. Pada keadaan normal, metabolik ini didetoksifikasi dengan konjugasi bersama glutation dalam bentuk asam merkapturat. Parasetamol dosis tinggi akan menyebabkan terbentuknya banyak metabolit toksik reaktif yang mengakibatkan persediaan glutation dalam sitosol habis sehingga metabolit reaktif tersebut berikatan dengan komponen makromolekul protein sel hepar yang mengakibatkan kerusakan hepar (Rang, 2003).

Selain itu, NAPQI juga dapat menimbulkan stres oksidatif, yang berarti bahwa NAPQI dapat menyebabkan terjadinya peroksidasi lipid. Peroksidasi lipid merupakan bagian dari proses atau rantai terbentuknya radikal bebas. Radikal bebas mampu mengubah suatu molekul menjadi radikal bebas baru dan akan membentuk radikal bebas kembali sehingga terjadilah reaksi rantai (chain reaction). Kerusakan hepar akibat parasetamol dapat terjadi karena reaksi toksik, alergi, dan radikal bebas.

Adanya kerusakan sel-sel parenkim hepar atau permeabilitas membran akan mengakibatkan enzim GOT (Glutamate Oksaloasetat Transaminase) dan enzim GPT (Glutamate Piruvat Transaminase) akan keluar dari sel hepar sehingga akan menyebabkan peningkatan aktivitasnya dalam serum darah (Gajawat et al., 2006).
Tetapi indikator yang lebih baik adalah SGPT karena peningkatan SGPT bertahan lebih lama dibanding peningkatan aktivitas SGOT (Tietz et al., 2001).

Rerata aktivitas SGPT pada kelompok hewan coba yang diberi parasetamol dosis tinggi (97.06 U/L) menunjukkan perbedaan bermakna $(p=0.016)$ bila dibandingkan dengan kelompok hewan coba yang diberi parasetamol dosis tinggi dan ekstrak alga merah (82.73 U/L). Keadaan ini menunjukkan bahwa ekstrak alga merah dapat menurunkan secara bermakna aktivitas SGPT setelah induksi parasetamol dosis tinggi.

Alga merah (Gracilaria verrucosa) mengandung senyawa-senyawa yang dapat berperan sebagai antioksidan seperti asam fenolik, flavonoid, karotenoid, dan klorofil a dan b (Lestario, 2008). Asam fenolik adalah senyawa organik aromatik pada tumbuhan. Senyawa fenolik memberi rasa yang unik, aroma, dan khasiat yang menyehatkan pada sayur-sayuran dan buah-buahan. Klorofil adalah pigmen hijau pada tumbuhan. Ada beberapa bentuk klorofil. Klorofil a merupakan pigmen fotosintetik utama pada tumbuhan hijau dan berguna untuk mengubah energi cahaya menjadi energi kimiawi. Klorofil b merupakan pigmen aksesori pada fotosintesis yang dapat mengubah energi cahaya menjadi klorofil a. Asam fenolik 
serta klorofil a dan b berperan sebagai antioksidan dengan mendonorkan hidrogen dan akan bereaksi dengan senyawa oksigen reaktif sehingga dapat merusak pembentukan radikal bebas yang baru. Selain itu, asam fenolik juga dapat menghambat enzim sitokrom P450 sehingga pembentukan senyawa reaktif pada metabolisme parasetamol dapat ditekan (Pereira et al, 2009; Barberan and Espin, 2001; Glimn and Kaufman PB. 2006). Flavonoid merupakan senyawa polifenol yang mengandung 15 atom karbon dalam inti dasarnya, yang tersusun dalam konfigurasi $\mathrm{C}_{6}-\mathrm{C}_{3}-\mathrm{C}_{6}$, yaitu 2 cincin aromatik yang dihubungkan oleh satuan 3 karbon yang dapat atau tidak dapat membentuk cincin ketiga. Flavonoid meningkatkan ekspresi enzim Glutation Stransferase (GST) sehingga mempercepat proses detoksifikasi NAPQI melalui konjugasi dengan GSH menjadi asam merkapturat bersifat hidrofilik sehingga mudah diekskresikan melalui urin. Flavonoid akan mereduksi radikal bebas, menghasilkan senyawa yang lebih stabil dan kurang reaktif (Nurt, 2001; Katzung and Bertram, 2010).

Karotenoid dapat berfungsi sebagai peredam singlet oxygen dan pendeaktifasi radikal bebas. Mekanisme karotenoid sebagai peredam singlet oxygen adalah :
${ }^{1} \mathrm{O}_{2}+{ }^{1}$ Karotenoid akan diubah menjadi ${ }^{3} \mathrm{O}_{2}$ $+{ }^{3}$ Karotenoid

Sedangkan reaksi pendeaktivasi radikal bebas sebagai berikut :

$\mathrm{R}^{*}+$ Karotenoid akan diubah menjadi $\mathrm{RH}+$ Karotenoid*

$\mathrm{R}^{\prime}+$ Karotenoid akan diubah menjadi $\mathrm{R}^{-}+$ Karotenoid ${ }^{+}$

Karotenoid memiliki aktivitas antioksidan yang sangat dibutuhkan untuk meredam senyawa oksidan sehingga kerusakan hepar dapat dikurangi (Oktaviani et al, 2014; Panjaitan et al, 2005)

Berdasarkan pembahasan diatas dapat disimpulkan bahwa pemberian ekstrak alga merah (Gracilaria verrucosa) dosis $200 \mathrm{mg} / \mathrm{kgBB} / \mathrm{hari}$ pada tikus menurunkan secara bermakna aktivitas SGPT pada kelompok tikus yang diinduksi parasetamol dosis tinggi dan mendapat ekstrak alga merah (Gracilaria verrucosa) bila dibandingkan dengan kelompok tikus yang diinduksi parasetamol dosis tinggi tanpa mendapat ekstrak alga merah (Gracilaria verrucosa).

\section{KESIMPULAN}

Berdasarkan analisis data dan interpretasi hasil penelitian maka dapat disimpulkan bahwa Pemberian parasetamol dengan dosis $1750 \mathrm{mg} / \mathrm{kgBB}$ mampu meningkatkan secara bermakna aktivitas SGPT tikus putih (Rattus 
Pengaruh Pemberian Ekstrak Alga Merah (Gracilaria verrucosa) terhadap Aktivitas SGPT pada...

Akbar Maharudin Fikri, Sihning EJ Tehupuring

norvegicus) jantan galur Wistar. Pemberian

ekstrak alga merah (Gracilaria verrucosa)

dengan dosis $200 \mathrm{mg} / \mathrm{kgBB} / \mathrm{hari}$ mampu

menurunkan aktivitas SGPT secara

bermakna pada kelompok tikus putih

(Rattus norvegicus) jantan galur Wistar yang diinduksi parasetamol dosis tinggi.

\section{DAFTAR PUSTAKA}

Barberan TF, Espin JC, 2001. Phenolic Compounds and Related Enzymes as Determinants of Quality of Fruits and Vegetables. Jour Sci Food Agric.

Chan K, Han XD, and Kan, 2001. An Important Function of Nrf2 in Combating Oxidative Stress: Detoxification of Acetaminophen. USA: Proc Nati Acad Sci.

Farrel SE, 2014. Acetaminophen toxicity. Medscape. Diakses 20 April 2016. http://emedicine.medscape.com/ article/820200-overview

Gajawat S, Sancheti G, and Goyal PK, 2006. Protection Against Lead Induced Hepatic Lesion in Swiss Albino Mice by Absorbis Acid. Pharmologionline. 1: 140-149.

Ghosh A and Sil PC, 2007. Anti-oxidative effect of protein from Gajenus indicus L. Against acetaminophene induced hepato- nephro toxicity. I Biochem Mol Biol. 40 (6): 1039-1049.

Glimn LJ, Kaufman PB, 2006. Inroduction to Plants, Major Groups, Flowering Plant Families $2^{\text {nd }}$ edition. USA.

Guyton AC dan Hall JE, 2008. Fisiologi Kedokteran. Edisi 11. Jakarta: EGC.

Hariyatmi, 2004. Kemampuan Vitamin E Sebagai Antioksidan terhadap Radikal Bebas pada Usia lanjut. Jurnal MIPA UNS. 14: 52-60

Imron M dan Munif A, 2010. Metodologi Penelitian Bidang Kesehatan. Sagung Seto.Jakarta

Indriani H dan Sumiarsih, 1991. Budidaya, Pengolahan, dan Pemasaran Rumput Laut. Penebar Swadaya. Jakarta

Katzung, Bertram G, 2010. Farmakologi Dasar dan Klinik. Penerbit Buku Kedokteran EGC. Jakarta

Lestario L, Sugiarto S, dan Timotius. 2008. Aktivitas Antioksidan dan Kadar Fenolik Total dari Ganggang Merah (Gracilaria verrucosa). Jurnal Teknologi dan Industri Pangan. 19: 131-138

Nurt, 2001. Flavonoids: a review of probable mechanisms of action and potential applications. American Society for Clinical Nutrition. 
Oktaviani, Purwijantiningsih EP, Ekawati

LM, Pranata, Finung, 2014.

Kualitas dan Aktivitas Antioksidan

Minuman Probiotik dengan

Ekstrak Buah Naga merah.

Universitas Atmajaya. Yogyakarta.

Panjaitan, Duharman T, Prasetyo, Budhi,

Limantara, Leenawaty, 2005.

Peranan Karotenoid Alami Dalam

Menangkal Radikal Bebas di

Dalam Tubuh. USU

Pereira $\mathrm{M}$, Valentao $\mathrm{P}$, Pereira J, and Andrade P, 2009. Phenolics From Chemistry to Biology. Journal Molecules Porto University. 14:2202-2211

Rang HP, Dale MM, and Moore PK, 2003. Pharmacology, $5^{\text {th }}$ edition, 239235, 562-570. Churcill Livingstone. London

Sato M, Imai K, Murata T, 1980. Effect of Sodium Copper Chlorophyllin on Lipid Peroxidation: The Antioxidative Activities of The Commercial Preparation of Sodium Copper Chlorophyllin.

Soegiarto A, Sulistijo, Atmadja WS, and Mubarak, 1978. Rumput Laut (Algae). Lembaga Oseanologi Nasional - LIPI. Jakarta.

Tietz NW, Burtis CA, Ashwood ER, 2001. Tietz Fundamental of Clinical Chemistry $5^{\text {th }}$ Edition.
Philadelphia, Toronto. W.B. Saunders Company. London 